\title{
Competent users and standards of use for Autism Diagnostic Interview - Revised (ADI-R) and Autism Diagnostic Observation Schedule, Second Edition (ADOS-2)
}

Kompetentni użytkownicy i standardy użytkowania wywiadu do diagnozowania autyzmu ADI-R (Autism Diagnostic Interview - Revised) oraz protokołu obserwacji do diagnozowania zaburzeń ze spektrum autyzmu ADOS-2 (Autism Diagnostic Observation Schedule, Second Edition)

\author{
'Neurodevelopmental Disorders Research Lab, Institute of Experimental and Clinical Medicine, Faculty of Medicine, University of Rzeszów, Rzeszów, Poland \\ ${ }^{2}$ Centre for Diagnosis, Therapy and Education SPECTRUM ASC-MED, Gdańsk, Poland \\ ${ }^{3}$ Department of Psychiatry, UCSFWeill Institute for Neurosciences, University of California, San Francisco (UCSF), San Francisco, USA \\ ${ }^{4}$ Children and Adolescent Mental Health Services (CAMHS), Tees, Esk and Wear Valleys NHS Foundation Trust, Stockton-On-Tees, United Kingdom \\ ${ }^{5}$ Department of Child and Adolescent Psychiatry, Poznan University of Medical Sciences, Poznan, Poland \\ ${ }^{6}$ Department of Psychiatry and Psychotherapy, Medical University of Silesia in Katowice, Katowice, Poland \\ ${ }^{7}$ John Paul II Paediatric Centre in Sosnowiec Sp. z 0.0., Sosnowiec, Poland \\ ${ }^{8}$ Department of Developmental Psychiatry, Psychotic and Geriatric Disorders, Medical University of Gdańsk, Gdańsk, Poland \\ Correspondence: Agnieszka Rynkiewicz, Neurodevelopmental Disorders Research Lab, Institute of Experimental and Clinical Medicine, Faculty of Medicine, University of Rzeszów, \\ Warzywna 1A, 35-310 Rzeszów, tel.: +48 17851 68 56, e-mail: arynkiewicz@ur.edu.pl
}

\author{
'Pracownia Badań Zaburzeń Neurorozwojowych, Instytut Medycyny Doświadczalnej i Klinicznej, Wydział Medyczny, Uniwersytet Rzeszowski, Rzeszów, Polska \\ ${ }^{2}$ Centrum Diagnozy, Terapii i Edukacji SPECTRUM ASC-MED, Gdańsk, Polska \\ ${ }^{3}$ Department of Psychiatry, UCSFWeill Institute for Neurosciences, University of California, San Francisco (UCSF), San Francisco, USA \\ ${ }^{4}$ Children and Adolescent Mental Health Services (CAMHS), Tees, Esk and Wear Valleys NHS Foundation Trust, Stockton-On-Tees, Wielka Brytania \\ ${ }^{5}$ Klinika Psychiatrii Dzieci i Młodzieży, Uniwersytet Medyczny w Poznaniu, Poznań, Polska \\ ${ }^{6}$ Katedra Psychiatrii i Psychoterapii, Śląski Uniwersytet Medyczny w Katowicach, Katowice, Polska \\ ${ }^{7}$ Centrum Pediatrii im. Jana Pawła II w Sosnowcu Sp. z 0.0., Sosnowiec, Polska \\ ${ }^{8}$ Klinika Psychiatrii Rozwojowej, Zaburzeń Psychotycznych i Wieku Podeszłego, Gdański Uniwersytet Medyczny, Gdańsk, Polska \\ Adres do korespondencji: Agnieszka Rynkiewicz, Pracownia Badań Zaburzeń Neurorozwojowych, Instytut Medycyny Doświadczalnej i Klinicznej, Wydział Medyczny, Uniwersytet Rzeszowski, \\ ul. Warzywna 1A, 35-310 Rzeszów, tel.: +48 17851 68 56, e-mail: arynkiewicz@ur.edu.pl
}

\begin{abstract}
Autism Diagnostic Interview - Revised (ADI-R) and Autism Diagnostic Observation Schedule, Second Edition (ADOS-2) are well-validated semi-structured instruments, widely used in clinical practice and research for decades. They both follow highly standardised procedures to provide a thorough assessment of individuals suspected of having autism spectrum disorder (ASD). Both instruments have been found to be useful in differentiating between children, adolescents and adults with ASD and those with non-ASD diagnoses, especially when both are used in combination. As with many measures of ASD symptoms, scores on ADI-R and ADOS-2 have been shown to be susceptible to effects of developmental variables, including age and IQ as well as behavioural difficulties of a subject. Experienced clinicians are aware that the scores can be affected by comorbidity or sex of an individual, which is the case in females with autism who have not been diagnosed early in life or those who do not have intellectual disability and/or profound communication difficulties. The article presents ADI-R and ADOS-2 in a succinct way along with basic recommendations for their use, which are the same regardless of location and country. The purpose of this article is to present guidelines and standards of use for ADI-R and ADOS-2 which are distinguished from the standards of purchase. Administration and coding of ADI-R and ADOS-2 are highly standardised, and based on these guidelines, only professionals who completed ADI-R and ADOS-2 test-specific trainings can be considered competent users to provide valid assessments.
\end{abstract}

Keywords: ADOS-2, ADI-R, users, assessments, standards 
Streszczenie Wywiad do diagnozowania autyzmu ADI-R (Autism Diagnostic Interview - Revised, ADI-R) oraz protokół obserwacji do diagnozowania zaburzeń ze spektrum autyzmu ADOS-2 (Autism Diagnostic Observation Schedule, Second Edition) to rzetelnie zwalidowane i wystandaryzowane narzędzia, od dziesięcioleci szeroko stosowane w praktyce klinicznej i badawczej na świecie. Procedury wykonania badania przy użyciu obu narzędzi podlegają ściśle określonym normom, co umożliwia wszechstronną ocenę osób z podejrzeniem zaburzeń ze spektrum autyzmu (autism spectrum disorder, ASD). Wykazano przydatność obu narzędzi w różnicowaniu dzieci, adolescentów i dorosłych z ASD oraz tych z rozpoznaniami innymi niż ASD - zwłaszcza w przypadku łącznego zastosowania obu procedur. Tak jak w przypadku wielu innych narzędzi do oceny objawów ASD, wyniki uzyskane w testach ADI-R i ADOS-2 wykazują podatność na wpływ zmiennych rozwojowych, takich jak wiek czy iloraz inteligencji oraz trudności behawioralne osoby badanej. Doświadczeni klinicyści są świadomi tego, że na uzyskane wyniki mają także wpływ współchorobowość oraz płeć osoby badanej, co ilustrują przykłady kobiet z autyzmem niezdiagnozowanym w wieku rozwojowym bądź osób bez niepełnosprawności intelektualnej czy znacznych trudności komunikacyjnych. Niniejszy artykuł w zwięzły sposób przybliża narzędzia ADI-R i ADOS-2, a także podstawowe rekomendacje dotyczące ich zastosowania, które są niezmienne niezależnie od kraju czy warunków wykonania badania. Celem pracy jest omówienie wytycznych i standardów użytkowania ADI-R i ADOS-2, które nie są tożsame ze standardami dotyczącymi zakupu obu narzędzi. Procedury wykonywania i kodowania ADI-R i ADOS-2 są wysoko wystandaryzowane. Zgodnie z obowiązującymi wytycznymi wyłącznie specjaliści, którzy ukończyli szkolenia w zakresie stosowania ADI-R i ADOS-2, mogą być ich kompetentnymi użytkownikami, a wyniki wykonanych przez nich badań są uznawane za rzetelne i wiarygodne.

Słowa kluczowe: ADOS-2, ADI-R, użytkownicy, narzędzia diagnostyczne, standardy

\section{INTRODUCTION}

A utism Diagnostic Interview - Revised (ADI-R) (Rutter et al., 2003) and Autism Diagnostic Observation Schedule, Second Edition (ADOS-2) (Lord et al., 1999) are well-validated semi-structured assessments, widely used in clinical practice and research. Both assessments have been used for decades worldwide and follow highly standardised procedures. ADI-R and ADOS-2 are useful in differentiating children, adolescents and adults with autism spectrum disorder (ASD) from those with non-ASD diagnoses, especially when both instruments are used in combination (Lord et al., 1999; Rutter et al., 2003). As with many measures of ASD symptoms, scores on ADI-R and ADOS-2 have been shown to be susceptible to effects of developmental variables, including age and IQ as well as behavioural difficulties of a subject (Havdahl et al., 2016). Experienced clinicians are aware that the degree of parent concern can also affect ADI-R scores (Havdahl et al., 2017). Additionally, the scores on ADOS-2 and ADI-R can be affected by comorbidity or sex of an individual (Rynkiewicz et al., 2018), for example being a female with autism not diagnosed early in life or the presence/absence of intellectual disability and/or profound communication difficulties (Ormond et al., 2018; Rynkiewicz et al., 2018, 2016). Thus, standardised instruments like ADOS-2 and ADI-R require competent users. The publishers, such as American WPS and British Hogrefe, clearly distinguish between qualifications to purchase and qualifications to use ADOS-2 and ADI-R. All professional groups, including physicians, psychologists, educators, speech and language therapists etc., are equally allowed to purchase ADOS-2 or ADI-R, with no degree-based restrictions - undergraduate (BA, BSc), master's (MA, MSc, MSW, CAGS) or doctoral degree (PhD, PsyD, MD) holders are accepted (ADOS-2 WPS; ADI-R WPS).

\section{WSTĘP}

$\mathrm{W}$ wiad do diagnozowania autyzmu ADI-R (Autism Diagnostic Interview - Revised) (Rutter et al., 2003) i protokół obserwacji do diagnozowania zaburzeń ze spektrum autyzmu ADOS-2 (Autism Diagnostic Observation Schedule, Second Edition) (Lord et al., 1999) to rzetelnie zwalidowane narzędzia, szeroko stosowane w praktyce klinicznej i badawczej. Używa się ich na świecie od dziesięcioleci, a procedury ich wykonywania są wysoko wystandaryzowane. Oba narzędzia są też przydatne w różnicowaniu dzieci, adolescentów i dorosłych $\mathrm{z}$ zaburzeniami ze spektrum autyzmu (autism spectrum disorder, ASD) i tych z rozpoznaniami innymi niż ASD - zwłaszcza w przypadku łącznego zastosowania tych procedur (Lord et al., 1999; Rutter et al., 2003). Jak w przypadku wielu innych narzędzi do oceny objawów ASD, wyniki uzyskane w ADI-R i ADOS-2 wykazują podatność na wpływ zmiennych rozwojowych, takich jak wiek czy iloraz inteligencji oraz trudności behawioralne osoby badanej (Havdahl et al., 2016). Doświadczeni klinicyści mają również świadomość faktu, iż na efekty testu ADI-R może także oddziaływać poziom zaniepokojenia rodziców czy opiekunów (Havdahl et al., 2017). Dodatkowo wpływ na wyniki uzyskane w ADOS-2 i ADI-R mają współchorobowość oraz płeć osoby badanej (Rynkiewicz et al., 2018), co ilustrują przykłady kobiet $\mathrm{z}$ autyzmem niezdiagnozowanym $\mathrm{w}$ wieku rozwojowym bądź osób bez niepełnosprawności intelektualnej czy znacznych trudności komunikacyjnych (Ormond et al., 2018; Rynkiewicz et al., 2018, 2016).

Należy podkreślić, że wystandaryzowane narzędzia diagnostyczne ADOS-2 i ADI-R wymagają stosowania przez kompetentnych użytkowników. Takie wydawnictwa jak amerykańskie WPS czy brytyjskie Hogrefe jasno rozdzielają i odróżniają kwalifikacje do zakupu od kwalifikacji do użytkowania ADOS-2 i ADI-R. Wszystkie uprawnione grupy zawodowe - tj. lekarze, psycholodzy, nauczyciele, logopedzi itp. - 
The Qualifications Guidelines of WPS and Hogrefe clearly state, however, who is considered a competent user, and that only professionals who have completed ADI-R and ADOS-2 test-specific trainings can reliably provide valid assessments (ADOS-2 WPS; ADI-R WPS; ADOS-2 Hogrefe; ADI-R Hogrefe). The WPS's website includes an FAQ section on this topic (ADOS-2 WPS; ADI-R WPS), as does Hogrefe (ADOS-2 Hogrefe; ADI-R Hogrefe). Although the exact nature of ADOS-2 and ADI-R trainings may somewhat differ between countries, the basic recommendation that all professionals complete ADI-R and ADOS-2 test-specific trainings remains the same regardless of location (ADOS-2 WPS; ADI-R WPS). In the case of ADOS-2/ADI-R in the UK, Hogrefe prefers to have the end user's training certificate in the use of the assessment (ADOS-2 Hogrefe; ADI-R Hogrefe). The local best practice standards for the use of ADOS-2 and ADI-R are jointly set forth by the local relevant professional organisations, health authorities, experts in autism and licensing boards. They represent such professions as psychology, child and adolescent psychiatry, paediatrics, adult psychiatry, neurology, education, speech and language therapy, and more. The aim of the paper is to increase knowledge of Polish professionals regarding purchase, use and best practice relative to ADOS- 2 and ADI-R as well as to serve as guidelines for developing standards and best practice for the use of these instruments in Poland.

\section{AUTISM DIAGNOSTIC OBSERVATION SCHEDULE, SECOND EDITION (ADOS-2)}

The ADOS-2 is a semi-structured assessment intended for individuals who are suspected of having ASD. The administration and coding are highly standardised. Therefore, training is required to ensure reliable and valid assessment (ADOS-2 WPS). The ADOS- 2 covers the areas of communication, social interaction, play, and restricted and repetitive behaviours. It evaluates autism-related symptoms and is based on real-time observations. The ADOS- 2 can be used by physicians, clinical psychologists, school psychologists, speech-language pathologists, occupational therapists, and other professionals. It can be used in different settings, such as hospitals, clinics, or schools which provide services for individuals with developmental disorders. The test is suitable for a wide population, from children aged 12 months up to adults. The administrator observes behaviours and translates them to codes, in an attempt to obtain information to facilitate diagnosis, educational placement as well as intervention and/or treatment planning. The ADOS- 2 consists of five different modules: T, 1, 2, 3 and 4 . The test administrator selects a module to be used, which needs to be appropriate for a subject's expressive language level and chronological age. For example, the Toddler Module (Module T) is suitable for children between 12 and 30 months of age who do not consistently use phrase speech. Module 1 is suitable for traktowane są w tym zakresie równo i mają możliwość zakupu ADOS-2 lub ADI-R bez ograniczeń dotyczących tytułu naukowego potencjalnego użytkownika (dr, dr n. med., lek. med. itp.) (ADOS-2 WPS; ADI-R WPS). Wytyczne dotyczące kwalifikacji wydawnictw WPS i Hogrefe jasno stanowią, kogo można uznać za kompetentnego użytkownika omawianych narzędzi. Wskazują mianowicie, iż są to wyłącznie osoby, które ukończyły odpowiednie szkolenie z zakresu ADI-R i ADOS-2, uprawniające do tego, aby wyniki wykonanych przez nich badań można było uznać za rzetelne i wiarygodne (ADOS-2 WPS; ADI-R WPS; ADOS-2 Hogrefe; ADI-R Hogrefe). Informacje na ten temat w postaci odpowiedzi na najczęściej zadawane pytania można znaleźć na stronie internetowej WPS (ADOS2 WPS; ADI-R WPS) oraz Hogrefe (ADOS-2 Hogrefe; ADI-R Hogrefe). Chociaż charakter szkoleń z zakresu ADOS-2 i ADI-R może się nieznacznie różnić pomiędzy poszczególnymi krajami, to jednak podstawowe zalecenie - dotyczące ukończenia przez diagnostę specjalistycznego szkolenia z zakresu ADI-R i ADOS-2 - pozostaje niezmienne (ADOS-2 WPS; ADI-R WPS). W Wielkiej Brytanii w przypadku ADOS-2 i ADI-R wydawnictwo Hogrefe preferuje nawet opcję wglądu w certyfikat ukończenia szkolenia w zakresie stosowania danego narzędzia diagnostycznego przez jego użytkownika końcowego (ADOS-2 Hogrefe; ADI-R Hogrefe). Miejscowe standardy dotyczące dobrych praktyk w zakresie użytkowania ADOS-2 i ADI-R ustanawiane są w danym kraju wspólnie przez towarzystwa naukowe, władze zajmujące się ochroną zdrowia, ekspertów w dziedzinie autyzmu oraz organizacje przyznające prawa do wykonywania zawodu w poszczególnych dyscyplinach. Reprezentowane dziedziny obejmują psychologię, psychiatrię dzieci i młodzieży, pediatrię, psychiatrię dorosłych, neurologię, edukację, logopedię i inne. Niniejszy artykuł ma w zamyśle służyć podniesieniu świadomości polskich specjalistów na temat kupna, użytkowania i dobrych praktyk wykorzystania ADOS-2 i ADI-R, stanowiąc wytyczne pomocne w określaniu standardów użytkowania tych narzędzi diagnostycznych w Polsce.

\section{PROTOKÓŁ OBSERWACJ DO DIAGNOZOWANIA ZABURZEŃ ZE SPEKTRUM AUTYZMU ADOS-2 (AUTISM DIAGNOSTIC OBSERVATION SCHEDULE, SECOND EDITION)}

ADOS-2 to częściowo ustrukturyzowane narzędzie przeznaczone do badania osób z podejrzeniem ASD. Procedura jego wykonywania i kodowania jest wysoko wystandaryzowana, zatem do uzyskania rzetelnych i wiarygodnych wyników niezbędne jest specjalistyczne szkolenie (ADOS-2 WPS). ADOS-2 skupia się na obszarach komunikacji, interakcji społecznej, zabawy oraz ograniczonych (sztywnych) i powtarzalnych (stereotypowych) wzorców zachowań. Ocenie na podstawie obserwacji w czasie rzeczywistym podlegają objawy typowe dla ASD. ADOS-2 wykonują lekarze, psychologowie kliniczni i szkolni, pedagodzy, logopedzi, terapeuci zajęciowi i inni przeszkoleni specjaliści. Przeznaczony jest do stosowania w szpitalach, 
children aged 31 months and older who do not consistently use phrase speech. Module 2 is suitable for children of any age who use phrase speech but are not verbally fluent. Module 3 is suitable for verbally fluent children and young adolescents. Finally, Module 4 is suitable for verbally fluent older adolescents and adults. The administration of ADOS-2 takes 40-60 minutes. Each module has its own Protocol Booklet and algorithm form where the administrator enters codes and scores. The algorithm scores in Modules 1 through 4 are compared with the cut-off scores and yield one of three classifications, which might be autism, autism spectrum or non-spectrum. The algorithms in Module T (Toddler) yield "ranges of concern" which form clinical impressions instead of classifications, as it may not be appropriate to attribute such classification in children of that young age. However, the Toddler Module scores indicate that a child is at risk and their development should be closely monitored.

The administration and coding of ADOS- 2 are highly standardised and only professionals who completed ADOS-2 test-specific trainings can be considered its competent users who provide reliable and valid assessments (ADOS-2 WPS; ADOS-2 Hogrefe; McCrimmon and Rostad, 2014). Any professional considering using ADOS-2 in any formal research is required to complete additional training (ADOS-2 WPS; ADOS-2 Hogrefe).

\section{AUTISM DIAGNOSTIC INTERVIEW - REVISED (ADI-R)}

The Autism Diagnostic Interview - Revised (ADI-R) is a comprehensive interview used in the assessment of children, adolescents and adults suspected of having ASD. The ADI- $\mathrm{R}$ is effective in differentiating autism from other developmental disorders. Apart from its contribution to the diagnostic process, it also aids clinical decision-making and planning relative to treatment and education. The administration and coding of the ADI-R are highly standardised. Valid assessment requires training, during which the professional is familiarised with interview administration and practices accurate coding. The administration and scoring take between an hour and half up to two and half hours. An experienced interviewer asks questions to a parent or any carer who can provide information on the developmental history and current behaviour of the assessed individual. The ADI-R consists of 93 items which evaluate three functional domains of (1) language and communication, (2) reciprocal social interactions as well as (3) restricted, repetitive, and stereotyped behaviours and interests. The interviewer asks questions to obtain information which cover eight areas including:

1. the individual's background, including family, education, previous diagnoses, and medications;

2. overview of the individual's behaviour;

3. early development and developmental milestones; poradniach i placówkach edukacyjnych dla osób z zaburzeniami neurorozwojowymi. Wykonuje się go u dzieci w wieku od 12 miesięcy wzwyż oraz u osób dorosłych. Diagnosta obserwuje i koduje zachowania badanego w celu uzyskania informacji przydatnych do: ustalenia rozpoznania, ukierunkowania interwencji lub leczenia oraz wyboru bądź dostosowania trybu i/lub programów kształcenia. W skład ADOS-2 wchodzi pięć modułów: T, 1, 2, 3 i 4. Diagnosta dokonuje wyboru modułu, który musi być dostosowany do wieku chronologicznego i poziomu rozwoju mowy czynnej u osoby badanej. I tak Moduł T (Toddler Module) przeznaczony jest dla dzieci w wieku pomiędzy 12. a 30. miesiącem życia bez w pełni rozwiniętej mowy zdaniowej. Moduł 1 opracowano dla dzieci w wieku 31 miesięcy i powyżej bez w pełni rozwiniętej mowy zdaniowej. Moduł 2 skierowany jest do dzieci w dowolnym wieku, które używają mowy zdaniowej, jednak bez umiejętności płynnego mówienia. Moduł 3 przeznaczono dla dzieci i młodszych adolescentów płynnie mówiących. Wreszcie moduł 4 opracowany został dla starszych adolescentów i dorosłych płynnie mówiących. Czas trwania obserwacji przy użyciu ADOS-2 wynosi około 40-60 minut. Do każdego modułu dostępne są odrębny protokół badania oraz algorytm diagnostyczny, w którym diagnosta wpisuje kody i oceny punktowe. Wyniki uzyskane w algorytmach diagnostycznych do Modułów 1-4 porównuje się z wartościami granicznymi (cut-off scores) i przyporządkowuje do jednej z trzech kategorii: ,autyzm”, „spektrum autyzmu” lub „poza spektrum autyzmu”. Algorytm diagnostyczny do Modułu T daje wynik w postaci różnych „poziomów niepokoju". Poziomy te formułują spostrzeżenia kliniczne, zamiast przypisywać jednoznaczne kategorie, co byłoby niewłaściwe z uwagi na bardzo młody wiek badanych dzieci. Wyniki Modułu T sygnalizują jednak, że dziecko zalicza się do grupy ryzyka i należy monitorować jego dalszy rozwój.

Procedura wykonywania i kodowania ADOS- 2 jest wysoko wystandaryzowana. Wyłącznie specjaliści, którzy ukończyli szkolenie w zakresie stosowania ADOS-2, mogą więc być jego kompetentnymi użytkownikami, uzyskującymi rzetelne i wiarygodne wyniki badań (ADOS-2 WPS; ADOS-2 Hogrefe; McCrimmon i Rostad, 2014). Specjaliści rozważający wykorzystanie tego narzędzia w badaniach naukowych muszą ukończyć dodatkowe szkolenie w tym zakresie (ADOS-2 WPS; ADOS-2 Hogrefe).

\section{WYWIAD DO DIAGNOZOWANIA AUTYZMU ADI-R (AUTISM DIAGNOSTIC INTERVIEW - REVISED)}

Wywiad do diagnozowania autyzmu ADI-R to wszechstronne narzędzie przeznaczone do oceny diagnostycznej dzieci, adolescentów i dorosłych z podejrzeniem ASD. ADI-R skutecznie różnicuje autyzm od innych zaburzeń rozwojowych. Przydaje się nie tylko w procesie diagnostycznym, lecz także przy planowaniu terapii i oddziaływań edukacyjnych. Procedura wykonywania i kodowania ADI-R jest wysoko wystandaryzowana. Do uzyskania rzetelnych i wiarygodnych wyników niezbędne jest więc specjalistyczne szkolenie, w trakcie którego diagnosta uczy 
5. current functioning in regard to language and communication;

6. social development and play;

7. interests and behaviours;

8. clinically relevant behaviours, such as aggression, self-injury or possible epilepsy.

The interviewer scores and interprets the results using agespecific and comprehensive algorithm forms. Two diagnostic algorithms are based on developmental history and used for formal diagnosis. Three current behaviour algorithms focus on present functioning and are used for treatment and educational planning. The results can support diagnosis of autism (ASD) or provide information about the clinical needs of a subject being evaluated.

Administration and coding of ADI-R is highly standardised, and only professionals who complete ADI-R specific trainings can be competent in providing valid assessments (ADI-R WPS; ADI-R Hogrefe). Any professional considering using ADI-R in any formal research is required to complete additional training (ADI-R WPS; ADI-R Hogrefe).

\section{CONCLUSION}

Standardised assessments for the diagnosis of autism spectrum disorder, such as ADOS-2 and ADI-R, are currently being implemented in Poland. It is therefore legitimate to popularise the knowledge of standards for their use and to make the professionals aware that these standards are clearly separated from the entitlement to purchase. It is also legitimate to present examples of relevant best practice, which helps develop competent users of these diagnostic instruments worldwide.

\section{Conflict of interest}

The authors do not report any financial or personal connections with other persons or organisations, which might negatively affect the content of this publication and/or claim authorship rights to this publication.

\section{Funding/Support and role of the sponsor}

This work has been supported by the Polish-U.S. Fulbright Commission. Grant № P000698. Project: "Autism symptomatology in females and ADOS-2." Project Institution: Neurodevelopmental Disorders Research Lab, Institute of Experimental and Clinical Medicine, Faculty of Medicine, University of Rzeszów. Specialist: Bryan King. Field of study: Public/Global Health. się przeprowadzać wywiad i ćwiczy kodowanie odpowiedzi. Przeprowadzenie wywiadu i jego ocena punktowa zajmują $1,5-2,5$ godziny. Doświadczony diagnosta zadaje pytania rodzicowi lub opiekunowi, znającemu przebieg rozwoju i bieżących zachowań osoby badanej. ADI-R składa się z 93 pytań, odnoszących się do trzech dziedzin funkcjonowania, tj.: (1) języka i komunikacji, (2) wzajemności interakcji społecznych oraz (3) ograniczonych, powtarzalnych i stereotypowych wzorców zachowań oraz zainteresowań. Diagnosta zadaje pytania w celu uzyskania wiedzy z ośmiu obszarów, które obejmują:

1. sytuację rodzinną, proces edukacji, ustalone rozpoznania i przyjmowane leki;

2. informacje ogólne dotyczące zachowania osoby badanej;

3. wczesny rozwój i kroki milowe w rozwoju;

4. nabywanie i utratę umiejętności, w tym językowych;

5. bieżące funkcjonowanie w odniesieniu do mowy i komunikacji;

6. rozwój społeczny i zabawę;

7. zainteresowania i zachowania;

8. zachowania istotne klinicznie, takie jak agresja, samookaleczenia lub możliwa padaczka.

Następnie diagnosta przypisuje oceny punktowe i interpretuje wyniki przy pomocy algorytmów diagnostycznych dostosowanych do wieku osoby badanej. Dwa algorytmy diagnostyczne oparte są na pytaniach dotyczących historii rozwojowej osoby badanej i wykorzystuje się je do formalnej diagnozy autyzmu. Trzy algorytmy diagnostyczne aktualnego zachowania - ukierunkowane na ocenę bieżącego funkcjonowania osoby badanej - służą do planowania terapii i interwencji edukacyjnych. Uzyskane wyniki stanowią pomoc w diagnostyce autyzmu (ASD) lub dostarczają informacji o klinicznych potrzebach osoby badanej.

Procedura wykonywania i kodowania ADI-R jest wysoko wystandaryzowana. Wyłącznie specjaliści, którzy ukończyli szkolenie w zakresie stosowania ADI-R, mogą więc być jego kompetentnymi użytkownikami, uzyskującymi rzetelne i wiarygodne wyniki badań (ADI-R WPS; ADI-R Hogrefe). Specjaliści rozważający wykorzystanie ADI-R w badaniach naukowych muszą ukończyć dodatkowe szkolenie w tym zakresie (ADI-R WPS; ADI-R Hogrefe).

\section{PODSUMOWANIE}

Wystandaryzowane narzędzia do diagnozowania zaburzeń ze spektrum autyzmu, takie jak ADOS-2 i ADI-R, są obecnie wprowadzane w Polsce. Zasadna jest zatem popularyzacja wiedzy dotyczącej standardów ich użytkowania. Ważne wydaje się też uświadamianie specjalistów, iż są one wyraźnie oddzielane od standardów zakupu obu testów. Ponadto za istotne należy uznać prezentowanie przykładów dobrych praktyk i kształcenia kompetentnych użytkowników tych narzędzi diagnostycznych w innych krajach.

\section{Konflikt interesów}

Autorzy nie zgłaszaja żadnych finansowych ani osobistych powiązań $z$ innymi osobami lub organizacjami, które mogtyby negatywnie wplynać na treść publikacji oraz rościć sobie prawo do tej publikacji. 


\section{References / Piśmiennictwo}

ADI-R. Autism Diagnostic Interview-Revised. Hogrefe, United Kingdom. Available from: https://www.hogrefe.co.uk/shop/ autism-diagnostic-interview-revised.html [cited: 2 October 2018].

(ADI $\left.{ }^{\mathrm{m}}-\mathrm{R}\right)$ Autism Diagnostic Interview ${ }^{\mathrm{met}}$, Revised. WPS, USA. Available from: https://www.wpspublish.com/store/p/2645/adi-rautism-diagnostic-interview-revised [cited: 2 October 2018].

ADOS-2. Autism Diagnostic Observation Schedule, 2nd Edition. Hogrefe, United Kingdom. Available from: https://www.hogrefe. co.uk/shop/autism-diagnostic-observation-schedule-2nd-edition. html [cited: 2 October 2018].

$\left(\mathrm{ADOS}^{\mathrm{m}}-\right.$-2) Autism Diagnostic Observation Schedule ${ }^{\mathrm{m} w}$, Second Edition. WPS, USA. Available from: https://www.wpspublish.com/ store/p/2648/ados-2-autism-diagnostic-observation-schedule-second-edition [cited: 2 October 2018].

Havdahl KA, Bishop SL, Surén P et al.: The influence of parental concern on the utility of autism diagnostic instruments. Autism Res 2017; 10: 1672-1686.

Havdahl KA, Hus Bal V, Huerta M et al.: Multidimensional influences on autism symptom measures: implications for use in etiological research. J Am Acad Child Adolesc Psychiatry 2016; 55: 1054-1063.e3.

Lord C, Rutter M, DiLavore PC et al.: Autism Diagnostic Observation Schedule (ADOS). Western Psychological Services, Los Angeles, CA 1999.

\section{Źródło finansowania}

Praca wspierana przez Polsko-Amerykańska Komisję Fulbrighta. Grant № P000698. Projekt „Symptomatologia autyzmu u dziewcząt a ADOS-2". Instytucja projektowa: Pracownia Badań Zaburzeń Neurorozwojowych, Instytut Medycyny Doświadczalnej i Klinicznej, Wydział Medyczny, Uniwersytet Rzeszowski. Specjalista: Bryan King. Dziedzina: Ochrona zdrowia na świecie.

McCrimmon A, Rostad K: Test Review: Autism Diagnostic Observation Schedule, Second Edition (ADOS-2) Manual (Part II): Toddler Module. J Psychoeduc Assess 2014; 32: 88-92.

Ormond S, Brownlow C, Garnett MS et al.: Profiling autism symptomatology: an exploration of the Q-ASC parental report scale in capturing sex differences in autism. J Autism Dev Disord 2018; 48: 389-403.

Rutter M, Le Couteur A, Lord C: Autism Diagnostic Interview-Revised (ADI-R). Western Psychological Services, Los Angeles, CA 2003.

Rynkiewicz A, Lassalle A, King B et al.: Females and autism. In: Montgomery $\mathrm{H}$ (ed.): Oxford Bibliographies in Childhood Studies. Oxford University Press, New York 2018.

Rynkiewicz A, Schuller B, Marchi E et al.: An investigation of the 'female camouflage effect' in autism using a computerized ADOS-2 and a test of sex/gender differences. Mol Autism 2016; 7: 10. 